\title{
Synthesis, Antioxidant, Molecular Docking And DNA Interaction Studies of Metal Based Imine Derivatives
}

\section{Muhammad Ibrahim ( $\square$ lbrahim189@yahoo.com )}

Abdul Wali Khan University Mardan (AWKUM) KPK

\section{Ashfaq Ahmad \\ King Saud University}

\section{Fouzia Perveen}

National University of Sciences and Technology (NUST)

\section{Hazrat Un Nabi}

Abdul Wali Khan University Mardan (AWKUM) KPK

\section{Niaz Muhammad}

Abdul Wali Khan University Mardan (AWKUM) KPK

\section{Muhammad Ikram}

Abdul Wali Khan University Mardan (AWKUM) KPK

Musadiq Ibrahim

University of Glasgow

\section{Abid Ali}

Abdul Wali Khan University Mardan (AWKUM) KPK

Jean Paul Kamdem

Universidade Federal de Santa Maria

Hassan M.Al-Swaidan

King Saud University

\section{Teixeira Rocha}

Universidade Federal de Santa Maria

\section{Research Article}

Keywords: Antioxidants, DNA binding, free radicals, Schiff base metal complexes

Posted Date: August 26th, 2021

DOI: https://doi.org/10.21203/rs.3.rs-778827/v1

License: (c) (i) This work is licensed under a Creative Commons Attribution 4.0 International License. Read Full License 


\section{Abstract}

Background: Currently, numerous investigations are ongoing into the interaction of free radicals with biological systems such as lipids, DNA and protein.

Methods: In the present work, synthesis, characterization, antioxidant, DNA binding and molecular docking studies of Schiff base ligand and its $\mathrm{Ni}(\mathrm{II}), \mathrm{Co}(\mathrm{II}), \mathrm{Cu}(\mathrm{II})$ and $\mathrm{Zn}(\mathrm{II})$ were evaluated.

Results: The metal complexes shown significant dose-dependent antioxidant activities comparable to the classical antioxidants, ascorbic acid and ethylene diaminetetraacetic acid (EDTA). The DNA binding constants ( $k$ b) were found to be $3.487 \times 10^{-5} \mathrm{M}^{-1}, 1.858 \times 10^{-5} \mathrm{M}^{-1}, 3.090 \times 10^{-5} \mathrm{M}^{-1}, 1.367 \times 10^{-5} \mathrm{M}^{-1}$ and $9.118 \times 10^{-5} \mathrm{M}^{-1}$ for $\mathrm{Ni}(\mathrm{II}), \mathrm{Co}(\mathrm{II}), \mathrm{Cu}$ (II) and $\mathrm{Zn}$ (II) metal complexes, respectively. Binding constants $(K b)$ and free energy $(\Delta G)$ values calculated from molecular docking analysis were found to be in close agreement with experimental results.

Conclusion: The obtained results indicate the importance of synthesis complexes as a source of synthetic antioxidants and anticancer drugs.

\section{Background}

Free radicals are highly reactive species containing one or more unpaired electrons. They donate or take electrons from other molecules in an attempt to pair their elections and generate a more stable species [1, 2]. Free radicals are generated within the body during normal metabolic activities, stimulation of macrophages, leucocytes, aerobic respiration and other metabolic processes, on the other hand tobacco smoke, pollutants, ionizing radiations, organic solvents and pesticides are the major exogenous sources of free radicals production in biological systems. For instance, ROS/RNS are markedly involved in many signaling pathways that control development and maintain cellular homeostasis $[3,4]$. However excess production of these free radicals either internally or transferred from environment have a great impact on human in the etiology of various diseases. Although, the body possesses defense mechanisms as antioxidant nutrients and enzymes which arrest the damaging properties of free radicals. Continuous exposure to chemicals and contaminants may increase the amount of free radicals in the body beyond its ability to control and cause irreversible oxidative damages [5].

Therefore, antioxidants with free radical scavenging potential may be relevant in the therapeutic and preventions of diseases where free radicals are implicated. In addition to natural antioxidants such as vitamin C, vitamin E, carotenoids flavonoids a number of synthetic antioxidants like butylatedhydroxyltoluene (BHT), butylatedhydroxyanisole (BHA), tertiary butylhydroquinone and Schiff base metal complexes have been prepared and their antioxidant capacity has been assessed for the prevention of various diseases [6, 7].In the present study, the synthesis, characterization, antioxidant, DNA binding activity, molecular docking studies of newly synthesized Schiff base ligand and its $\mathrm{Co}(\mathrm{II}), \mathrm{Ni}(\mathrm{II}), \mathrm{Cu}(\mathrm{II})$ and $\mathrm{Zn}$ (II) complexes were evaluated in vitro. The names of compounds along with their structures employed in the present work are given in Fig. 1.

\section{Methods}

\section{Chemicals}

Salicylaldehyde, aniline, 2,2-Diphenyl-1-picrylhydrazyl radical (DPPH), ferrous sulphate, Ascorbic acid, ethylenediaminetetraacetic acid (EDTA), Tris HCl buffer, ferric chloride, O-phenenthroline, sulfuric acid, ammonium molybdate, Potassium phosphate (mono phosphate and diphosphate), Hydrogen peroxide, ethanol, Salmon fish DNA of analytical grade were purchased from Sigma Aldrich.

\section{Synthesis of 2-[(E)-(phenylimino)methyl]phenol (H-Pimp)}

The Schiff base ligand H-pimp was synthesized by reacting the methanolic solution of $5 \mathrm{mmol}$ of aniline with $5 \mathrm{mmol}$ salicyladehyde. Yellowish product was produced instantaneously upon mixing. Crude product was filtered and recrystallized 
from concentrated metahanolic solution.

Yield: 63\%, M.Pt: $48^{\circ} \mathrm{C}$, Elemental analysis (C13H11NO): Calc. C(79.16\%), H(5.62\%), N(7.10\%), Exp. C(80.63\%), $H(5.12 \%), N(7.01 \%)$, IR analysis $\left(\mathrm{cm}^{-1}\right): 3200$ (w), 1569 (s), 1483(s), 1407(s), 1363(s), 1282(s), 1156(s), 1110(s), 987(s), 912(s), 857(s), 756(s), 688(s), ${ }^{1} \mathrm{H} \mathrm{NMR}(300.13 \mathrm{MHz}, \mathrm{CDCl} 3,303 \mathrm{k}) \delta=6.8\left(\mathrm{~d},{ }^{3} \mathrm{JHH}=7.03 \mathrm{~Hz}, 1 \mathrm{H}, \mathrm{H} 13\right), 6.91\left(\mathrm{~d},{ }^{3} \mathrm{JHH}=7.03\right.$ $\mathrm{Hz}, 2 \mathrm{H}, \mathrm{H} 12$ \& H14), 6.94 (d, ${ }^{3} \mathrm{JHH}=7.01 \mathrm{~Hz}, 2 \mathrm{H}, \mathrm{H} 4$ \& H5), $7.02\left(\mathrm{~d},{ }^{3} \mathrm{JHH}=7.2 \mathrm{~Hz}, 1 \mathrm{H}, \mathrm{H} 3\right), 7.11\left(\mathrm{~d},{ }^{3} \mathrm{JHH}=7.31 \mathrm{~Hz}, 2 \mathrm{H}, \mathrm{H} 11\right.$ and $\mathrm{H} 15), 7.3\left(\mathrm{~d},{ }^{3} \mathrm{JHH}=6.9 \mathrm{~Hz}, 1 \mathrm{H}, \mathrm{H6}\right), 8.53(\mathrm{~s}, \mathrm{Ar} \mathrm{HC} \mathrm{N}), 10.0(\mathrm{~s}, \mathrm{OH}),{ }^{13} \mathrm{C}\left\{{ }^{1} \mathrm{H}\right\}-\mathrm{NMR}(75.47 \mathrm{MHz}, \mathrm{CDCl} 3,303 \mathrm{k}), 110(\mathrm{CH}$, C13), 112 (CH, C12 \& C14), 112.1 (CH, C4 \& C5), 113 (CH, C3), 126 (CH, C11 and C15), 133 (CH, C6), 133 (C, C2), 148 (C, C1), 153 (C, C10), 159 (CH, Ar HC-N).

\section{Synthesis of transition metal complexes with H-pimp Schiff base ligand}

The transition metal complexes of the H-pimp Schiff base ligand were synthesized by following the same procedure as reported [8]. The metal salts were initially dehydrated by keeping the acetate salts of $\mathrm{Co}(\mathrm{II}), \mathrm{Ni}(\mathrm{II}), \mathrm{Cu}(\mathrm{II})$ and $\mathrm{Zn}$ (II) in an oven for $3-4 \mathrm{~h}$ at $110^{\circ} \mathrm{C}$. Methanolic solution of H-pimp ( $\left.5 \mathrm{mmol}\right)$ was added to the methanolic solution of metal acetate $(2 \mathrm{mmol})$ and stirred for $3 \mathrm{~h}$. The product was either instantly soon after the reaction or obtained through concentration using rotary evaporator.

\section{Bis(2-[(E)-(phenylimino)methyl]phenolate)cobalt(II) (Co-pimp)}

Yield; 43\%, elemental analysis, C26H20CoN2O2, Calc. C(69.18\%) H(4.47\%) Co (13.06\%) N(6.21\%) Found C(69.88\%) H(5.11\%) Co(13.02\%) N(6.12\%) IR analysis: 1536(s), 1482(s), 1465(s), 1450(s), 1328(s), 1180(s), 1148(s), 1122(s), 1086(s), 1010(s), 976(s), 929(s), 858(s), 837(s), 758(s), 698(s) $\mathrm{cm}^{-1}, \lambda \max =860 \mathrm{~nm}\left(\varepsilon=17.6 \mathrm{M}^{-1} \mathrm{~cm}^{-1},{ }^{2} \mathrm{~A} 2 \mathrm{~g} \rightarrow{ }^{2} \mathrm{~B} 1 \mathrm{~g}\right)$.

\section{Bis(2-[(E)-(phenylimino)methyl]phenolate)nickel(II) (Ni-pimp)}

Yield; 55\%, elemental analysis, C26H20N2NiO2, Calc. C(69.22\%) H(4.47\%) N(6.21\%) Ni(13.01\%) Found. C(69.28\%) H(4.90\%) $\mathrm{N}(6.29 \%) \mathrm{Ni}(12.11 \%)$, IR analysis: 1533(s), 1464(s), 1443(s),1416(s), 1343(s), 1260(s), 1224(s), 1181(s), 1147(s), 1123(s), 1033(w), 981(s), 946(s), 871(w), 821(s), 810(s), 761(s), 751(s), 728(s), 689(s), 671(s) cm ${ }^{-1}, \lambda \max =690 \mathrm{~nm}\left(\varepsilon=28.3 \mathrm{M}^{-1}\right.$ $\left.\mathrm{cm}^{-1},{ }^{1} \mathrm{~A} 1 \mathrm{~g} \rightarrow{ }^{1} \mathrm{~A} 2 \mathrm{~g}\right)$.

\section{$\operatorname{Bis(2-[(E)-(phenylimino)methyl]phenolate)copper(II)~(Cu-pimp)~}$}

Yield; 68\%, elemental analysis, C26H20CuN2O2, Calc. C (68.48\%) H (4.42\%) Cu (13.94\%) N (6.14\%) Found. C (69.33\%) H (4.92\%) Cu (13.01\%) N(7.44\%) IR analysis: 1555(s), 1523(s), 1478(s), 1441(s), 1388(s), 1351(s), 1323(s), 1255(s), 1205(w), 1175(s), 1151(s), 1133(s), 1098(s), 1031(s), 1009(s), 987(s), 937(s), 834(s), 767(s), 699(s), 623(s) $\mathrm{cm}^{-1}, \lambda \max =660 \mathrm{~nm}(\varepsilon=$ $\left.188.6 \mathrm{M}^{-1} \mathrm{~cm}^{-1}, \mathrm{dz}^{2} \rightarrow \mathrm{dx}^{2}-\mathrm{y}^{2}\right)$.

\section{$\operatorname{Bis(2-[(E)-(phenylimino)methyl]phenolate)zinc(II)~(Zn-pimp)~}$}

Yield; 55\%, elemental analysis, C26H20N2O2Zn, Calc. C (68.20\%) H (4.40\%) N (6.12\%) Zn (14.29\%) Found. C (70.01\%) $\mathrm{H}(4.78 \%) \mathrm{N}(6.89 \%)$ Zn (14.95\%), IR analysis: 1581(s), 1531(s), 1459(s), 1441(s), 1389(s), 1351(s), 1326(s), 1253(s), 1169(s), 1151(s), 1096(s), 1032(s), 1008(s), 927(s), 829(s), 789(s), 762(s), 688(s), 596(s) $\mathrm{cm}^{-1}$.

\section{Determination of $I n$-Vitro antioxidant studies}

\section{DPPH radical scavenging assay}

The antioxidant activity of the newly synthesized compounds were assessed using the stable DPPH free radical according to Ibrahim et al.2017 [7]. Various concentrations (50, 100, 200 and $400 \mu \mathrm{M})$ of compounds were mixed with ethanolic solution containing $85 \mu \mathrm{M}$ DPPH radical. The decrease in absorbance was measured at $518 \mathrm{~nm}$ using a UV-Visible Spectrophotometer. 
Ascorbic acid was used as positive control to determine the maximal decrease in DPPH absorbance. The values are expressed in percentage of inhibition of DPPH absorbance in relation to the control values without the compounds (ascorbic acid maximal inhibition was considered $100 \%$ of inhibition).

\section{Ferrous ion-chelating assay}

The ferrous ion chelating activity of newly synthesized compounds were analyzed by a standard method Puntel et al., 2005[8]. Various concentrations ( $50 \mu \mathrm{M}, 100 \mu \mathrm{M}, 200 \mu \mathrm{M}$, and

$400 \mu \mathrm{M}$ ) of compounds were mixed with $0.2 \mathrm{ml}$ of $3.6 \mathrm{mM}$ ferrous sulphate, $0.3 \mathrm{ml}$ of $100 \mathrm{mM}$ Tris- $\mathrm{HCl}(\mathrm{pH}=7.4), 0.1 \mathrm{ml}$ of 9 $\mathrm{mM}$ 0-Phenanthroline and diluted up to $3.0 \mathrm{ml}$ with ultra-pure distal water. The reaction mixture was shaken vigorously, incubated for 10 minutes and the decrease in absorbance was determined at $510 \mathrm{~nm}$. EDTA (ethylenediaminetetraacetic acid) at the same concentrations utilized as a reference standard and without Schiff bases complexes .

\section{Ferric Reducing / Antioxidant Power Assay}

The ferric reducing power of the newly synthesized compounds were determined according to (Kumar et al., 2012) [9]. Different concentrations $(50,100,200,100$ and $200 \mu \mathrm{M})$ of compounds, $0.2 \mathrm{ml}$ of $3.6 \mathrm{mM}$ ferric chloride, $0.3 \mathrm{ml}$ of $100 \mathrm{mM}$ tris buffer ( $\mathrm{pH}=7.4), 0.1 \mathrm{ml}$ of $9 \mathrm{mM}$ 0-phenanthroline and diluted up to $3.0 \mathrm{ml}$ with ultra-pure distal water. It was shaken for 10 min vigorously and left to stand at room temperature. The increase in absorbance of the sample solution was measured at $510 \mathrm{~nm}$ using a UV-Visible Spectrophotometer. Ascorbic acid at the same concentrations was utilized as a reference standard and without compounds sample mixture as control.

\section{Total antioxidant activity (Phosphomolybdenum assay)}

The total antioxidant capacity of newly synthesized compounds were evaluated by phosphomolybdenum assay (Sahaa et al., 2008)[10]. Reagent solution containing various concentrations $(50,100,200$ and $400 \mu \mathrm{M})$ of compounds aliquot in ethanol, $0.7 \mathrm{ml}$ of $0.6 \mathrm{M}$ sulphuric acid, $1.0 \mathrm{mM}$ ammonium molybdate, $1.0 \mathrm{ml}$ of $28 \mathrm{Mm}$ pottasium pasphate and ultra pure distal water was incubated at $95^{\circ} \mathrm{C}$ for $90 \mathrm{~min}$. After cooling, at room temperature the increase in absorbance of the mixture is measured at $695 \mathrm{~nm}$ using an V-730 UV-Visible/NIR Spectrophotometer. Ascorbic acid was utilized as reference standard and without compounds sample mixture as control.

\section{Hydroxyl radical scavenging activity}

The scavenging activity of all the synthesized complexes for hydroxyl radicals were measured with Fenton reaction by (Li et al., 2011)[11]. Reaction mixture of various concentrations (50, 100, 200 and $400 \mu \mathrm{M})$ of Ni(II), Co(II), Cu(II) and Zn(II) metal complexes, $0.1 \mathrm{~mL}$ of $7.5 \mathrm{mM}$ 0-phenanthroline, $0.5 \mathrm{ml}$ of $0.2 \mathrm{M}$ phosphate buffer ( $\mathrm{pH} 6.6), 0.1 \mathrm{~mL}$ of $7.5 \mathrm{mM}$ ferrous sulfate and $0.1 \mathrm{~mL}$ of $\mathrm{H} 2 \mathrm{O} 2(0.1 \%)$ and diluted up to $3 \mathrm{~mL}$ with distilled water. The reaction mixture incubated at room temperature for $30 \mathrm{~min}$ and the absorbance was measured at $510 \mathrm{~nm}$ using a UV-Visible Spectrophotometer. The reaction mixture without Schiff base complexes has been used as control and without Schiff base complexes and H2O2 as a blank.

\section{DNA Absorption spectroscopic studies}

The interaction between metal complexes and DNA were studied using electronic absorption method. Solution of Salman fish DNA in the buffer $50 \mathrm{mM} \mathrm{NaCl} / 5 \mathrm{mM}$ Tris- $\mathrm{HCl}(\mathrm{pH} 7.2)$ in water gave a ratio 1.9 of UV absorbance at 260 and $280 \mathrm{~nm}$, indicating that the DNA was sufficiently free from protein [12]. The concentration of DNA was measured using its extinction coefficient at $260 \mathrm{~nm}\left(6600 \mathrm{M}^{-1} \mathrm{~cm}^{-1}\right)$ after 1:100 dilution. Concentrated stock solutions of the complexes were prepared by dissolving the complexes in ethanol and diluting suitably with the corresponding buffer to the required concentration for all of the experiments. The data were then fitted to the Equation 6 to obtain the $k b$ values for interaction of the complexes with DNA. 


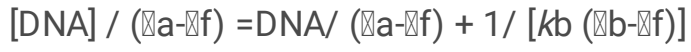

Where $\nabla a, \nabla f$, and $\nabla b$ are the apparent, free and bound metal complex extinction coefficients, respectively. A plot of [DNA]/ (『b$\nabla f)$ versus $[D N A]$, gave a slope of $1 /(\nabla b-\nabla f)$ and a $Y$-intercept equal to $[k b /(\nabla b-\nabla f)]^{-1} ; k b$ is the ratio of the slope to the $Y$ intercept.

\section{Statistical analysis}

Linear regression analysis was used to calculate IC50 5 SEM values from data and graphs by using Graph pad prism $6 \AA$ (Motulsky and Neubig, 2001). Significant differences among the means of data were tested by the one-way ANOVA followed by the student's t-test with significance level $(P<0.05)$. All the tests were conducted in triplicate

\section{Molecular docking methodology}

The chemical structure of the Schiff base ligand and its complexes with $\mathrm{Co}(\mathrm{II}), \mathrm{Ni}(\mathrm{II}), \mathrm{Cu}(\mathrm{II})$ and $\mathrm{Zn}$ (II) were sketched and optimized on MOE2017 window using MOE molecular builder and were entered into MOE database. 3-D structure of DNA with PDB ID-1D66, resolution of 2.7 and sequence of CCGGAGGACTGTCCTCCGG was obtained from the RCSB protein Data Bank [13]. For the purpose of docking simulation PDB internal coordinates of DNA were optimized using molecular dynamic AMBER force field and semi-empirical PM3 approaches to attain minimum energy and stable conformation. Water molecules were removed from DNA structures by sequence editor of MOE to exclude effect of water on interaction of DNA with the ligand and its metal complexes. Structures was protonated with their standard geometry followed by their energy optimization tool using MOPAC 7.0. The resulting structures were subjected to systematic conformational search at default parameters with RMS gradient of $0.01 \mathrm{kcal} / \mathrm{mol}$ using Site Finder to find out active sites of DNA molecule. Finally a number of docking runs were carried out to get a final binding pose from scoring function. The best conformation was selected on the basis of energetic ground and the minimum Final Docking Energy $(\Delta \mathrm{G})$ [14-15].

\section{Results And Discussion}

The Schiff base ligand 2-[(E)-(phenylimino)methyl]phenol (H-pimp) was synthesized by the condensation reaction of salicylaldehyde with aniline. It was characterized through different spectroscopic and analytical techniques. The uncorrected melting temperature was observed around $48^{\circ} \mathrm{C}$. The infrared spectral data of the H-pimp Schiff base ligand reveal a peak around $3200 \mathrm{~cm}^{-1}$ assigned to the $\mathrm{NH}$ stretch. The peak is weakly observed because of the possible intramolecular hydrogen bonding viz; given in scheme 1.

The broad peak for hydroxyl stretch is obscured by the NH band appearance. The azomethine is observed at the expected position. The formation of the ligand is further supported by the NMR spectra. The ${ }^{1} \mathrm{H}-\mathrm{NMR}$ of the H-pimp Schiff base ligand reveal a singlet assigned each for azomethine moiety and the phenolic hydroxyl group. Rest of the spectrum show peaks for the aromatic protons. ${ }^{13} \mathrm{C}\left\{{ }^{1} \mathrm{H}\right\}$-NMR show imine peak at $159 \mathrm{ppm}$, and the hydroxyl peak at $148 \mathrm{ppm}$. The Schiff base ligand was reacted further with metal ions in 2:1 molar ratio to produce metal derivatives of the anionic ligand with [M(pimp)2] compositions. The schematic representation of the metal derivatives is shown in scheme 2:

The IR spectra of the metal complexes share combine features of bonding irrespective of the metal center. The H-pimp ligand is behaving as monoanionic ligand offering coordination sites like $\mathrm{O}^{-}$and $\mathrm{HC}=\mathrm{N}$. Both the stretching bands were seen displaced from the position observed in the spectrum of the free ligand. Rest of the spectra show differences due to the complexation. The elemental compositions in metal complexes also reveal closeness for the [M(pimp)2] compositions in all the metal complexes. Therefore, it has been observed unambiguously that the metal complexation occurs through bonding of two molecules of the ligand with metal centers. The metal complexes were also observed to be non-electrolyte in nature.

The UV-visible spectra of the metal complexes were recorded within the region $320-800 \mathrm{~nm}$ in methanolic solutions. The Copimp complex show a single and broad band at 860nm assigned to the distorted square planar ${ }^{2} \mathrm{~A} 2 \mathrm{~g} \rightarrow{ }^{2} \mathrm{~B} 1 \mathrm{~g}{ }^{1} \mathrm{~A} 1 \mathrm{~g} \rightarrow{ }^{1} \mathrm{~B} 1 \mathrm{~g}$ 
and ${ }^{1} \mathrm{~A} 1 \mathrm{~g} \rightarrow$ Eg were considered enfolded within the broad ${ }^{2} \mathrm{~A} 2 \mathrm{~g} \rightarrow{ }^{2} \mathrm{~B} 1 \mathrm{~g}$ transition [2]. Similarly the visible spectrum of Ni-pimp metal complex also reveal a single transition ${ }^{1} \mathrm{~A} 1 \mathrm{~g} \rightarrow{ }^{1} \mathrm{~A} 2 \mathrm{~g}$ for the $\mathrm{C} 2 \mathrm{v}$ symmetry. The Cu-pimp show a weak transition at 660 $\mathrm{nm}$ assigned to the $\mathrm{dz}^{2} \rightarrow \mathrm{dx}^{2}-\mathrm{y}^{2}$ in distorted tetrahedral geometry. All the transitions in metal complexes were assigned charge transfer ligand to metal transitions where the imine group is involved in donating the electron density toward metal orbitals.

\section{DPPH radical scavenging assay}

The IC50 value for ligand was found to be $333.58 \pm 5.771 \mu \mathrm{M}$ highest among the tested compounds. The IC50 values for the synthesized complexes are ranging from 150 to $196 \mu \mathrm{M}$. The IC50 value for ascorbic acid was found to be $121.07 \pm 15.94$. These activities were dose reliant and maximum DPPH scavenging activity was observed at higher concentrations.

\section{Ferrous ion-chelating assay}

Figure 3 shows the $\mathrm{Fe}^{2+}$ chelating properties of ethanolic solution of Schiff base Ligand and its metal complexes and EDTA (ethylenediaminetetraacetic acid). The IC50 value for ligand was found to be $297.45 \pm 5.771 \mu \mathrm{M}$ highest among the tested compounds. The IC50 values for the synthesized complexes are ranging from 138 to $180 \mu \mathrm{M}$. The IC50 values for EDTA was found to be 135 .

\section{Ferric Reducing / Antioxidant Power Assay}

The compound reduction power may serve as a significant indicator of its potential antioxidant activity [6-7]. Table 3 and Fig. 4 shows the reductive competences of the Schiff base ligand and its metal complexes when compared to the standard, Ascorbic acid. The IC50 value for ligand was found to be $293.28 \pm 6.538 \mu \mathrm{M}$ highest among the tested compounds. The IC50 values for the synthesized complexes are ranging from 130 to $162 \mu \mathrm{M}$. The IC50 values for Ascorbic acid was found to be 99.

Table 2

Free energy $(\Delta \mathrm{G})$, binding constant $(\mathrm{Kb})$ of ligand and its metal complexes calculated from molecular docking data.

\begin{tabular}{|lll|}
\hline Complex & Free Energy $(-\Delta G) / \mathrm{kJ} / \mathrm{mol}$ & Binding Constants $\left(K_{b}\right) \mathbf{M}^{-1}$ \\
\hline $\mathrm{H}$-pimp & 31.56 & $3.14 \times 10^{5}$ \\
$\mathrm{Ni}(\text { pimp })_{2}$ & 30.29 & $1.88 \times 10^{5}$ \\
$\mathrm{Co}(\text { pimp })_{2}$ & 31.22 & $2.73 \times 10^{5}$ \\
$\mathrm{Cu}(\text { pimp })_{2}$ & 29.87 & $1.59 \times 10^{5}$ \\
\hline $\mathrm{Zn}(\text { pimp })_{2}$ & 32.79 & $5.04 \times 10^{5}$ \\
\hline
\end{tabular}


Table 3

Data set of selected electronic descriptors calculated from molecular docking data.

\begin{tabular}{|lllllll|}
\hline Complex & $\mathrm{E}_{\text {Total }} / \mathrm{kcalmol}$ & $\mathrm{E}_{\mathrm{HOMO}} / \mathrm{kcal} / \mathrm{mol}$ & $\mathrm{E}_{\mathrm{LUMO}} / \mathrm{kcal} / \mathrm{mol}$ & $\mathrm{E}_{\text {electro }} / \mathrm{kcal} / \mathrm{mol}$ & $\mathrm{E}_{\mathrm{vandr}} / \mathrm{kcal} / \mathrm{mol}$ & $\mathrm{E}_{\mathrm{IP}} / \mathrm{kcal} / \mathrm{mol}$ \\
\hline $\mathrm{H}$-pimp & -449908.307 & -8.8801 & 3.9700 & -296836.46 & 0.00000 & 8.8801 \\
\hline $\mathrm{Ni}(\mathrm{pimp})_{2}$ & - & - & - & - & 0.00000 & - \\
$\mathrm{Co}(\mathrm{pimp})_{2}$ & - & - & - & - & 0.00000 & - \\
\hline $\mathrm{Cu}(\mathrm{pimp})_{2}$ & - & - & - & - & 0.00000 & - \\
\hline $\mathrm{Zn}(\mathrm{pimp})_{2}$ & -99731.257 & -1.18563 & -0.4894 & -875361.812 & 0.00000 & -1.18563 \\
\hline
\end{tabular}

\section{Total antioxidant activity (Phosphomolybdenum assay)}

Total antioxidant capacity of Schiff base ligand and its metal complexes have been evaluated by phosphomolybdate method with ascorbic acid as a standard. The $\mathrm{Mo}(\mathrm{VI})$ is reduced to $\mathrm{Mo}(\mathrm{V})$, in the presence of drugs which shows maximum absorbance at $695 \mathrm{~nm}$. The IC50 value for ligand was found to be $264.41 \pm 7.532 \mu \mathrm{M}$ highest among the tested compounds. The IC50 values for the synthesized complexes are ranging from 120 to $155 \mu \mathrm{M}$. The IC50 values for Ascorbic acid was found to be 86 .

\section{Hydroxyl radical scavenging activity}

The hydroxyl radical scavenging activity of the Schiff base ligand and its metal complexes was investigated by 0phenanthroline method. The IC50 value for ligand was found to be $49.63 \pm 8.391 \mu \mathrm{M}$ highest among the tested compounds. The IC50 values for the synthesized complexes are ranging from 36 to $43 \mu \mathrm{M}$. The IC50 values for Ascorbic acid was found to be 29 .

Ligand (Z)-2-((phenyl-imino)methyl)phenol containing hydroxyl group at ortho position to benzene ring and nitrogen atom are interconnection between two rings. Oxygen atom of hydroxyl group having high electron donating power and acts as ring activating group.

Hence, the overall ligand acts as a rich $\pi$ electrons species and their antioxidant power have further enhanced by complexation with transition metals.

All the metal complexes containing the same two bidentate Ligands (Z)-2-((phenyl-imino)methyl)phenol attached at the same position and the antioxidant potential depend only on central metal atom. Zn(II) and $\mathrm{Cu}$ (II) Complexes shows almost same antioxidant as compared to $\mathrm{Ni}(\mathrm{II}), \mathrm{Co}(\mathrm{II})$ metal complexes.

\section{DNA Binding activity}

The electronic absorption spectroscopy is the most common way to investigate the interactions of various Schiff base metal complexes with DNA. In general, complex bound to DNA through intercalation usually results in hypochromism and red shift (bathochromism), due to the strong stacking interaction between aromatic chromophore of the complex aromatic $\pi$ rings and the base pairs of DNA. The H-pimp, Ni-pimp, Co-pimp, Cu-pimp, and Zn-pimp complexes showed absorption bands at 331, $325,427.5,387$ and $321 \mathrm{~nm}$ with increasing concentration of DNA. All the complexes showed hypochromicity and a redshifted charge transfer peak maxima in the absorption spectra. The absorption spectra of the H-pimp, Ni-pimp, Co-pimp, Cupimp, and Zn-pimp complexes in the absence and presence of SH DNA are given in Figs. 5, 6, 7, 8 and 9, respectively. With the addition of DNA, the absorption intensities are gradually decreased. A total of 10\% (for H-pimp), 15\% (for Ni-pimp), 17\% (for Co-pimp), 14\% (for Cu-pimp) and 16\% (for Zn-pimp) of hypochromicity with 2.0, 1.0, 1.5, 2.5 and 1.0 of red shift were obtained. The intrinsic binding constants for H-pimp, Cu-pimp, Ni-pimp, Co-pimp,] and Zn-pimp complexes are found to be 
$3.487 \times 10^{-5} \mathrm{M}^{-1}, 1.858 \times 10^{-5} \mathrm{M}^{-1}, 3.090 \times 10^{-5} \mathrm{M}^{-1}, 1.367 \times 10^{-5} \mathrm{M}^{-1}$ and $9.118 \times 10^{-5} \mathrm{M}^{-1}$, respectively (illustrated in Table 1) indicating a moderate intercalation between the complexes and Salmon fish DNA. These $k b$ values are much smaller than the typical classical intercalators. In order to compare the binding strength of the complexes with Salmon fish DNA the kb were obtained by monitoring the changes in the absorbance for the complexes with increasing concentration of DNA. The $k b$ was

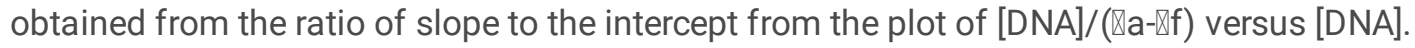

Table 1

The IC50 $(\mu \mathrm{M}) \pm$ SEM values of Ligand (H-pimp) and its metal complexes M(pimp)2a for different assays.

\begin{tabular}{|lllll|}
\hline Compound & DPPH assay & FRAP assay & TAA assay & 'OH assay \\
\hline $\mathrm{H}$-pimp & $333.58 \pm 5.771$ & $293.28 \pm 6.538$ & $264.41 \pm 7.532$ & $49.63 \pm 8.391$ \\
\hline $\mathrm{Ni}(\text { pimp })_{2}$ & $196.70 \pm 11.30$ & $145.90 \pm 11.00$ & $134.78 \pm 11.29$ & $39.41 \pm 14.32$ \\
\hline $\mathrm{Co}(\text { pimp })_{2}$ & $159.44 \pm 9.066$ & $153.66 \pm 11.65$ & $134.42 \pm 11.55$ & $43.19 \pm 13.62$ \\
\hline $\mathrm{Cu}(\text { pimp })_{2}$ & $150.51 \pm 10.95$ & $130.47 \pm 13.31$ & $120.93 \pm 11.76$ & $36.04 \pm 12.84$ \\
\hline $\mathrm{Zn}(\text { pimp })_{2}$ & $170.34 \pm 11.85$ & $162.90 \pm 10.61$ & $155.77 \pm 11.76$ & $36.91 \pm 15.01$ \\
\hline Ascorbic acid(AA) & $121.07 \pm 15.94$ & $99.612 \pm 16.91$ & $86.729 \pm 17.21$ & $29.25 \pm 17.21$ \\
\hline a Standard used is Ascorbic acid (AA) & & & \\
\hline
\end{tabular}

Table 4

Data set of selected steric descriptors calculated from molecular docking data.

\begin{tabular}{|llllll|}
\hline Complex & SlogP & HF & $\mathbf{M}_{\mathbf{R}}$ & Dipole moment & $\mathbf{V}_{\text {surf }}$ \\
\hline $\mathrm{H}$-pimp & 3.1428 & 28.3960 & 10.7179 & 3.4950 & 0.00000 \\
\hline $\mathrm{Ni}(\text { pimp })_{2}$ & 5.5234 & - & 7.9865 & 0.0000 & 0.00000 \\
\hline $\mathrm{Co}(\text { pimp })_{2}$ & 4.5117 & - & 9.4579 & 0.0000 & 0.00000 \\
\hline $\mathrm{Cu}(\text { pimp })_{2}$ & 6.1117 & - & 6.1803 & 0.0000 & 0.00000 \\
\hline $\mathrm{Zn}(\text { pimp })_{2}$ & 2.3745 & 96.1966 & 11.7197 & 16.9428 & 0.00000 \\
\hline
\end{tabular}

\section{Structural analysis and Molecular docking}

Structural analysis of (Z)-2-((phenylimino) methyl)phenol ligand and its metal complexes were carried out using semiepirical PM3 method Fig. 10(a-e) for their charge distribution and molecular docking with doubly stranded DNA (PDB:1D66). Molecular docking studies determined all possible configuration of computationally anticipated Schiff base ligand H-pimp, Ni-pimp, Co-pimp, Cu-pimp, and Zn-pimp complexes with DNA to understand the molecular mechanism and physical mode of interaction. DNA is the primary pharmacological target of number of anticancer compounds, and henceforth, the interaction between DNA and metal complexes are of vital prominence in understanding the mechanism. Transition metal complexes interact with DNA via both covalent and / or noncovalent interactions. Non-covalent DNA interactions include intercalative, electrostatic and groove binding of metal complexes with a DNA helix (Zhang et al., 2001). Pose view analysis of (Z)-2((phenylimino) methyl)phenol and its metal complexes was also performed to substantiate the mode of DNA binding and have been shown in Fig. 11(A). Least energy confirmation pose of (Z)-2-((phenylimino) methyl)phenol revealed that planar aromatic part of ligand intercalates between stacked base pairs of DNA by $\pi$-stacking interactions. 2D lig plot of the ligand 
showed that $\mathrm{H}$ of $\mathrm{H}-\mathrm{O}$ group develops $\mathrm{H}$-bonding with adenine DA (A8) of DNA whereas $\mathrm{O}$ of $\mathrm{H}-\mathrm{O}$ group builds $\mathrm{H}$-bonding with $\mathrm{H}$ atom of Guanine DG(A7) as shown in Fig. 7B(i). H-bonding characteristics of ligand rendered significantly high binding affinity with DNA (Table-2). Ni(II) complex of ligand exhibited mixed mode of intercalation and groove binding. It can be seen that Ph- ring of Zn(II) complex intercalates between DNA base pairs and rest of bulky structure stucks into minor groove of DNA establishing Vander Waal's interactions with groove as visible in Fig. 11. B(ii).It was observed that $\mathrm{Co}$ (II) and $\mathrm{Cu}$ (II) complexes of (Z)-2-((phenylimino) methyl) phenol fit well into minor groove of DNA via hydrophobic and Vander Waal's interactions (Fig. 11.B (iii-iv)) Interactions of Zn(II) complex with DNA are attributed to the intercalation of aromatic planar ring with flanking base pairs more importantly with DC(A14), DG(B26) and DT(A15) of DNA Fig. 11B(v). An substantial observation was that $\mathrm{Zn}(\mathrm{II})$ complex showed enhanced interactions and binding affinity in terms of highest $K b$ value as compared to free ligand and other complexes (Table-2). Negative value of free energy depicted that physical interaction mechanism of compounds with DNA has been proved to be spontaneous.

For the comprehension of microscopic interactions between DNA and (Z)-2-((phenylimino) methyl)phenol ligand as well as its complexes a number of physico chemical descriptors were calculated listed as electronic descriptors (Table -3$)$ and steric descriptors (Table-4).

Electronic parameters of the ligand and complexes were calculated, however semi empirical calculations of transition metal compounds were complicated due to partially filled d-orbitals of the metal ions that are responsible for the multifarious structures with large variety of possible coordination number and geometries [16-17]. Hence electronic parameters of only ligand and Zn complex (completely filled d-orbital) were determined. EHOMO and ELUMO values gave an estimate of the electron-donating or electron-accepting character of a given compound, consequently, a compound is considered more electron-donating as its EHOMO value increases and more electron accepting as its ELUMO value decreases. Table 3 depicts that Zn (II) complex is more electron donating as compared to ligand due to higher value of its EHOMO.

An excellent correlation of two steric parameters i.e., partition coefficient, (log P) and Molar refractivity (MR) with binding constant $(K b)$ has been perceived, Partition coefficient $(\log \mathrm{P})$ is illustrative of hydrophobicity of the molecule. In this work slogP revealed a reasonable inverse correlation with the $K b$ of ligand and its metal complexes $\left(R^{2}=0.885\right)$, indicating that the compounds with a lower slogP are anticipated to constitute stronger complexes (Fig. 12A).

Another imperative steric descriptor calculated in present work was Molar refractivity $(M R)$, a measure of the total polarizability of a mole of a substance and is dependance on the temperature, the index of refraction, and the pressure. A direct correlation of the MR $\left(R^{2}=0.8281\right)$ with $K b$ was indicative of the fact that compounds with higher MR have more binding affinity with DNA (Fig. 12B)

\section{Conclusions}

In the present study we performed the antioxidant and DNA binding study of a Schiff base ligand and its metal complexes. This preliminarily screening of these synthetic compounds reveals interesting antioxidant and DNA binding activities, however, these results cannot be extended directly to in vivo systems which are differ and more complex from in vitro studies. Additionally, the obtained result showed that it is interesting to note that metal complexes presented higher DPPH radical and $\mathrm{OH}$ radicals activities, $\mathrm{Fe}^{+2}$ chelation, reducing $\mathrm{Fe}(\mathrm{III})$ to $\mathrm{Fe}(\mathrm{II})$ and $\mathrm{Mo}(\mathrm{VI})$ to $\mathrm{Mo}(\mathrm{V})$ higher than free ligand. The findings of this study clearly indicated that the antioxidant effects of Schiff base ligand and its metal complexes, presented DPPH radical-scavenging activity, demonstrating the mechanism by which these drug displayed antioxidant activities. The ability of Schiff base Ligand and its metal complexes to show significant reducing power and to hunt DPPH radicals suggests that it is an electron donor and can react with free radicals to convert them to more stable products and terminate radical chain reactions. In conclusion the results presented in the present studies give information about the nature of antioxidants and DNA Binding intercalators found in Schiff base metal complexes. Structural analysis, Molecular docking and QSAR investigations presented highest binding affinity $\mathrm{Zn}$ (II) complex and lowest affinity for $\mathrm{Cu}$ (II) complex against DNA. Moreover computational calculated $K b$ values complemented experimentally determined $K b$ for UV-Vis spectroscopic results

Page 9/13 


\section{Abbreviations}

EDTA:ethylene diaminetetraacetic acid; ROS: Reactive oxygen species; RNS: Reactive nitrogen species; BHT:

butylatedhydroxyltoluene; BHA: butylatedhydroxyanisole

\section{Declarations}

\section{Acknowledgements}

This Research grant was supported by King Saude University ,Deanship of Scientific Research, College of Sciences Research Centre.

The authors gratefully acknowledge Abdul Wali Khan University Mardan (AWKUM) and King Saud University,

\section{Funding}

The authors are thankfull for the financial support of King Saude University ,Deanship of Scientific Research, College of Sciences Research Centre.

\section{Availability of data and materials}

All data generated or analyzed during this study are included in this published article .

\section{Authors' contributions}

Each author participated sufficiently in taking public responsibility for appropriate portions of the content. Study conception and design: Mol, FP, NM, and Mul, conceived the idea and designed experiments and wrote manuscript. HUN,AA and FP performed the experiments; MI, JPK analyzed the data; JBR revised the manuscript. All authors reviewed and approved the final version.

\section{Ethics approval}

Not applicable.

Consent for publication

Not applicable.

\section{Competing interests}

The authors declare that they have no competing interests

\section{References}

1. Halliwell B, Gutteridge JMC. Free Radicals in Biology and Medicine, fourth ed. Oxford University Press, Oxford. 2006

2. Valko M, Rhodes CJ, Moncol J, Izakovic M, Mazur M Free radicals, metals and antioxidants in oxidative stress-induced cancer. Chem Biol Interact. 2006; 160:1-40.

3. Perez-De La Cruz V, Gonzalez-Cortes C, Pedraza-Chaverri J, Maldonado PD, Andres-Martinez L, Santamaria A Protective effect of S-allylcysteine on 3-nitropropionic acid-induced lipid peroxidation and mitochondrial dysfunction in rat brain synaptosomes. Brain Res Bull. 2006;68:379-383.

4. Perez-Severiano F, Rodriguez-Perez M, Pedraza-Chaverri J, Maldonado PD, Medina-Campos ON, Ortiz-Plata A, SanchezGarcia A, Villeda-Hernandez J, Galvan-Arzate S, Aguilera P, Santamaria A S-allylcysteine, a garlicderived antioxidant, 
ameliorates quinolinic acid-induced neurotoxicity and oxidative damage in rats. Neurochem Int. 2004; 45:1175-1183.

5. Castill J, Rama R, Davalos A Nitric oxide-related brain damage in acute ischemic stroke. Stroke 2000; 31. 852-857.

6. Ibrahim M, Hassan W, Meinerz DF, Dos Santos MV, Klimaczewski CM, Deobald A, Costa MS, Nogueira CW, Barbosa NB, Rocha JB. In Vitro Antioxidant evaluation and DNA binding ability of $\mathrm{Ni}(\mathrm{II}), \mathrm{Co}(\mathrm{II}), \mathrm{Cu}(\mathrm{II})$ and $\mathrm{Zn}(\mathrm{II})$ metal complexes containing bidentate Schiff base. IOSR J App/ Chem. 2012;10:06-14.

7. Ganji N, Chityala VK, Marri PK, Aveli R, Narendrula V, Daravath S, Shivaraj, DNA incision evaluation, binding investigation and biocidal screening of $\mathrm{Cu}(\mathrm{II}), \mathrm{Ni}(\mathrm{II})$ and $\mathrm{Co}(\mathrm{II})$ complexes with isoxazole Schiff bases. J Photochem Photobio Bio 2017; 175:132-140.

8. Puntel RL. Nogueira CW, Rocha JB. Krebs cycle intermediates modulate thiobarbituric reactive species (TBARS) production in rat brain in vitro. Neurochem Res. 2005;30:225-235.

9. Kumar, RS, Raj KB, Perumal P. Antioxidant activities of Indigo feracassioides Rottl.Ex. DC. Using various in vitro assay models. Asian Pacif J Tro Dis 2012; 2:256-261.

10. Sahaa MR, Hasana SMR, Aktera R, Hossaina MM, Alamb MS, Alam MA, Mazumder MEH In vitro free radical scavenging activity of methanol extract of the leaves of Mimusopselengi Linn. Bangl J Vetery Medic 2008;6: 197-202.

11. Li P, Huo L, Su W, Lu R, Deng C, Liu L, Deng Y, Guo N, Lu C, He C Free radical-scavenging capacity, antioxidant activity and phenolic content of Pouzolziazeylanica. J. Serbian Chem Soc 2011:76;709-717.

12. Parnham MJ, Graf E Pharmacology of synthetic organic selenium compounds. Prog Drug Res. 1991; 36:947. https://www.rcsb.org/structure/1D66

13. Abdel-Hamid MK, Abdel-Hafez AA, El-Koussi NA, Mahfouz NM, Innocenti A, Supuran CT.Design, synthesis, and docking studies of new 1,3,4-thiadiazole-2-thione derivatives with carbonic anhydrase inhibitory activity. Bioorg Med Chem 2007;15:6975-6984.

14. Zhang QL, Liu JG. Chao H, Xue GQ, Ji LN DNA-binding and photocleavage studies of cobalt(III) polypyridyl complexes. J Inorg Biochem. 2001; 83:49-55.

15. Peter Comba, Trevor. W. Hambley and Bodo Martin.K.M. Honorio, A.B.F. Da Silva. Molecular Modeling of Inorganic compounds-Peter, Int. J. Quant. Chem. 2003;95: 126.

16. Patrick G Medicinal Chemistry by, Department of Chemistry and Chemical Engineering,fourth ed., Paisely University Paisley, Scotland. 2009

\section{Figures}

\section{Figure 1}

Structure of Schiff base ligand and their metal (Ni(II), $\mathrm{Co}(\mathrm{II}), \mathrm{Cu}(\mathrm{II}), \mathrm{Zn}(\mathrm{II}))$ complexes.

\section{Figure 2}

A: DPPH radical scavenging activity of Ligand and their metal complexes. (Ligand, Ni(II) Complex, Co(II) Complex, Cu(II) Complex, Zn(II) Complex and Ascorbic acid). Mean \pm SEM was used to expressed the values Significantly a $p<0.0006, b p<$ $0.0017, \mathrm{c} \mathrm{p}<0.0027, \mathrm{~d} \mathrm{p}<0.0086 \mathrm{~B}$ Ferrous ion-chelating activity of Ligand and their metal complexes. (Ligand, $\mathrm{Ni}(\mathrm{II})$ Complex, Co(II) Complex, Cu(II) Complex, Zn(II) Complex and EDTA) (Ethylenediaminetetraacetic acid). Values are expressed as mean \pm SEM (triplicate tests were conducted for each sample) Significantly a $p<0.0010, b p<0.0454, c p<0.0086, d p<$ 0.0062 , e $p<0.0095$, $\mathrm{p}<0.0033 \mathrm{C}$ Ferric ion reducing activity of Ligand and their metal complexes. Values are expressed as mean \pm SEM (triplicate tests were conducted for each sample). D Phosphomolybdenum assay of Ligand and their metal 
complexes. Values are expressed as mean \pm SEM (triplicate tests were conducted for each sample). E Hydroxyl scavenging assay of Ligand and their metal complexes. Values are expressed as mean \pm SEM (triplicate tests were conducted for each sample).

\section{Figure 3}

A: Absorption spectra of $\mathrm{H}$-pimp in buffer $\mathrm{pH} 7.2$ at $25^{\circ} \mathrm{C}$ in the presence of increasing amount of DNA. Arrows indicate the changes in absorbance upon increasing the DNA concentration. Inset: plot of [DNA] / (『a- $\mathbb{\text { f }}) \times 10-9 \mathrm{M} 2 \mathrm{~cm}$ versus [DNA] $\times 10-5$ $\mathrm{M}$ for titration of DNA with H-pimp. A: Absorption spectra of $\mathrm{H}$-pimp in buffer $\mathrm{pH} 7.2$ at $25^{\circ} \mathrm{C}$ in the presence of increasing amount of DNA. Arrows indicate the changes in absorbance upon increasing the DNA concentration. Inset: plot of [DNA] / (『a$\nabla f) \times 10-9 M 2 c m$ versus [DNA] $\times 10-5 \mathrm{M}$ for titration of DNA with H-pimp.

\section{Figure 4}

Figure legend not available with this version

\section{Figure 5}

Figure legend not available with this version

\section{Figure 6}

Figure legend not available with this version

\section{Figure 7}

Figure legend not available with this version

\section{Figure 8}

Figure legend not available with this version

\section{Image not available with this version}




\section{Figure 9}

Figure legend not available with this version

\section{Figure 10}

Figure legend not available with this version

\section{Figure 11}

Figure legend not available with this version

\section{Figure 12}

Figure legend not available with this version

\section{Supplementary Files}

This is a list of supplementary files associated with this preprint. Click to download.

- Scheme1.png

- Scheme2.png 